\title{
COMPARISON OF THE EFFECTIVENESS OF TOMATO (Lycopersicum commune) AND RED MELON (Cucumis melo L.) JUICE IN INCREASING VAGINAL WALL THICKNESS OF MENOPAUSAL RATS MODEL
}

\author{
Yhenti Widjayanti, Arief Widya Prasetya \\ Nursing Study Program, STIKES Catholic St. Vincent de Paul, Surabaya, Indonesia
}

\section{ABSTRACT}

\begin{abstract}
Menopausal period is the period of permanent cessation of menstruation due to reduced or lost ovarian activity. One of the effects of decline estrogen levels during menopause is atropic vulvovaginitis. Consumption of phytoestrogens can reduce menopausal symptoms. Phytoestrogen is found in vegetables and fruits such as tomatoes and red melon. The objective of this study was to compare the effectiveness of red melon juice and tomato on the increase of vaginal wall thickness in menopausal rats. This study revealed an alternative of phytoestrogen sources that is more effective to reduce menopausal symptoms, especially those related to vaginal atrophy to improve the quality of life of menopausal women. Subjects of this study were 27 ovariectomized Wistar strain Rattus norvegicus which were s divided into 3 groups randomly, one control group and two treatment groups with tomato juice and red melon juice at a dose of $330 \mathrm{mg} / \mathrm{kg}$ BW/day administered for 28 days. The variable of this study were the thickness of the vaginal wall which was precipitated by Hematoxiline Eosine. The highest vaginal wall thickness was found in the treatment group of red melon juice of $879.89 \pm 70.52 \mu \mathrm{m}$ and the lowest of the control group $(K)$ of $643.3 \pm 58.33 \mu \mathrm{m}$. The results of Anova test showed that there was a significant difference between control group and treatment groups, the tomato juice and red melon juice with a dose of $330 \mathrm{mg} / \mathrm{kgBW} /$ day, so it can be concluded that red melon juice with a dose of $330 \mathrm{mg} / \mathrm{Kg} \mathrm{BW} /$ day has the best effect in increasing the thickness of vaginal wall of menopausal rats as compared with tomato juice.
\end{abstract}

Keywords: Phytoestrogens; tomatoes; red melon; vaginal wall thickness; menopausal period

\section{ABSTRAK}

Menopause adalah periode berhentinya menstruasi secara permanen akibat berkurang atau hilangnya aktivitas ovarium. Salah satu dampak penurunan kadar estrogen pada masa menopause adalah atropic vulvovaginitis. Konsumsi fitoestrogen dapat mengatasi keluhan menopause. Fitoestrogen banyak terdapat pada sayuran dan buah-buahan antara lain tomat dan melon merah. Tujauan dari penelitian ini adalah membandingkan efektivitas jus melon merah dan tomat terhadap peningkatan ketebalan dinding vagina pada tikus model menopause. Hasil penelitian nantinya dapat memberikan gambaran alternatif konsumsi sumber fitoestrogen yang lebih efektif untuk mengatasi keluhan atropi vagina sehingga dapat meningkatkan kualitas hidup perempuan menopause. Subyek penelitian ini adalah hewan coba tikus Rattus norvegicus strain Wistar yang diovarektomi sebanyak 27 ekor yang di bagi dalam 3 kelompok secara random, satu kelompok kontrol dan dua kelompok perlakuan dengan pemberian jus tomat dan jus melon merah dengan dosis $330 \mathrm{mg} / \mathrm{kgBB} / \mathrm{hari}$ yang diberikan selama 28 hari. variabel penelitian ini adalah ketebalan sediaan vagina yang dipulas dengan HE. Rerata ketebalan dinding vagina tertinggi terdapat pada kelompok Perlakuan jus melon merah yaitu sebesar $879,89 \pm$ 70,52 um dan terendah dari kelompok kontrol (K) sebesar 643,3 $\pm 58,33 \mu \mathrm{m}$. Hasil uji Anova menunjukkan bahwa ada perbedaan yang bermakna antara semua kelompok kontrol dan kelompok perlakuan yaitu pemberian jus tomat dan jus melon merah dengan dosis pemberian $330 \mathrm{mg} / \mathrm{kgBB} / \mathrm{hari}$, sehingga dapat disimpulkan pemberian jus melon merah dengan dosis 330mg/Kg BB/hari memiliki efek yang paling baik dalam meningkatkan ketebalan dinding vagina tikus model menopause jika dibandingkan dengan pemberian jus tomat.

Kata kunci: Fitoestrogen; tomat; melon merah; ketebalan dinding vagina; menopause

Correspondence: Yhenti Widjayanti, Jl. Jambi 12-18 Surabaya, Indonesia. Phones: 031-5612220, 031-5663894. E-mail: yhentiwijayanti@gmail.com

pISSN:2355-8393 • eISSN: 2599-056x • doi: http://dx.doi.org/10.20473/fmi.v55i1.12564

- Fol Med Indones. 2019;55:159-165 • Received 9 Oct 2017• Accepted 24 May 2018

- Open access under CC-BY-NC-SA license • Available at https://e-journal.unair.ac.id/FMI/ 


\section{INTRODUCTION}

Along with increasing age, many processes of growth and development occur in humans. However, at one time the growth and development will stop at a stage, so, thereafter, many changes will occur in the function of the human body (Proverawati 2010). A definite change experienced by a woman is menopause. Menopause is the period of permanent cessation of menstruation due to reduced or lost ovarian activity. During menopause certain changes occur due to decreased estrogen levels which can cause mild to severe disorders. According to Sawitri (2009), one of the effects of decreased estrogen levels during menopause is atropic vulvovaginitis. Vaginal atrophy is experienced by $75-85 \%$ of postmenopausal women (Immanuel 2010). Symptoms of vaginal atrophy are expressed by $40 \%$ of menopausal women. Atrophy causes vaginal tissue to become thinner, easily irritated and also more prone to secondary infections. The impact of vaginal atrophy is dryness, vaginal discharge and dyspareunia (Immanuel 2010). During the thinning process of the vaginal epithelium, the $\mathrm{pH}$ of the vagina rises to become more alkaline, which results in an increased risk of vaginal infection or vaginitis atrophy.

The use of hormonal therapy is useful for preventing several conditions that can arise in menopausal women, including complaints of vaginal atrophy. However, this hormonal therapy, besides being relatively expensive, also increases the incidence of breast cancer. The administration of estrogen cream to the vagina aims to improve vaginal epithelium atrophy due to menopause. However, the administration must be careful so that no systemic effects occur, because the systemic effects due to the use of estrogen in the single form will increase the risk of endometrial hyperplasia and carcinoma (BPOM RI 2008). Phytoestrogens can be an alternative choice to replace hormone replacement therapy. Consumption of phytoestrogens can overcome menopausal complaints (Hanna, O-neil \& Wall, 2010). Phytoestrogens are found in many vegetables and fruits. The results showed that tomato juice is a source of phytoestrogens and can increase the thickness of the vaginal wall (Widjayanti 2013), also increase the elasticity of the vaginal wall in menopausal mouse models through increased collagen (Prasetya \& Widjayanti 2014). Putra's research results (2011) showed that red melon fruit is one source of phytoestrogens with estrogen levels of $1254.0 \pm 48.1$ $\mathrm{pg} / \mathrm{ml}$.

However, until now there has never been an evidence on the effect of red melon juice in dealing with complaints of vaginal atrophy. Given the importance of consumption of phytoestrogens to overcome vaginal atrophy complaints at menopause, research needs to be done to find the most effective source of phytoestrogens in overcoming these problems. A comparison needs to be made between the effectiveness of tomato juice and red melon juice in increasing the thickness of the vaginal wall. The results of the study may provide an alternative source of phytoestrogens that is more effective in dealing with vaginal atrophy, so as to improve the quality of life of menopausal women. This study used experimental animal models of the ovarianectomized Wistar strain Rattus norvegicus to obtain conditions resembling menopause in humans on the basis of ethical considerations because this study used vaginal tissue as a sample.

\section{MATERIALS AND METHODS}

Tomato juice given as a treatment in this study was produced from dry-freezing the inner side of tomatoes dissolved in $2 \mathrm{cc}$ of distilled water. Tomatoes used in this study came from Pacet, Mojokerto, Indonesia, which were planted at an altitude of 570 meters above sea level and red melons used in this study were from Ngawi District, Indonesia, planted at an altitude of 67 meters above sea level. Freeze-dried tomatoes and red melons were produced in phytochemical laboratories.

The model used in this study was female white rat Wistar strain Rattus novergicus aged 8-10 weeks and weighing $150 \pm 10$ grams obtained from the Biochemical Laboratory, Faculty of Medicine, Universitas Airlangga, Surabaya. The white rats are kept in cages made of plastic with a rice husk base and cover cages of woven wire, measuring $20 \times 40 \times 15 \mathrm{~cm}$. Each cage was filled with 4-5 experimental animals. The rats were given with distilled water drink and ad libitum rat feed in the form of homemade pellets with a composition of yellow corn flour, bran, fish meal, and oil (ratio 61: 32: 5: 2).

This study was a laboratory experimental study with post-test only control group design. Subjects were divided into 3 groups randomly, one control group and two treatment groups receiving tomato juice and red melon juice. Variable measurements were made at the end of the treatment. At the beginning of the study, control groups were subjected to homogenizing of the samples.

The variables in this study were tomato juice and red melon juice in a dose of $330 \mathrm{mg} / \mathrm{kgBW} /$ day given for 28 days as an independent variable and the other variable was the thickness of the vaginal wall as the dependent variable. The control variables in this study were the types of experimental animals, food, maintenance and 
treatment of experimental animals. Random variables in this study were stress level and nutrient absorption rate in the rats' digestive system.

The material examined was the vaginal wall of the experimental animal. Histopathological preparations of vaginal wall samples was made with hematoxylin eosin (HE) staining. The instrument used in this study was the result of measuring the thickness of a vaginal preparation stained with $\mathrm{HE}$. The obtained data were analyzed descriptively to determine mean and standard deviation of each group. Distribution normality test was carried out to find out whether the data were normally distributed and the homogeneity test was followed-up to determine the uniformity of variance using Levene test. Data were tested by one-way ANOVA test to test differences in the mean of vaginal wall thickness. $p$ $<0.05$ indicated at least a pair of group was different. Then, the test was followed-up with the least significant difference test to find the difference between the two treatment averages.

\section{RESULTS}

The results of this study were obtained from 29 ovariectomized white rats (Rattus novergicus). Samples were divided into 3 groups: 1 control group (K) receiving distilled water $2 \mathrm{cc} /$ day, 1 treatment group receiving tomato juice in a dose of $330 \mathrm{mg} / \mathrm{kg} / \mathrm{day}$ dissolved in 2 cc/day (P1) distilled water, and 1 group treatment receiving red melon juice in a dose of 330 $\mathrm{mg} / \mathrm{kg} /$ day dissolved in distilled water 2 cc/day (P2).

The thickness of the vaginal wall was defined as the thickness of the mucous layer (consisting of parabasal, intermediate and superficial cells) from tunica adventisia to superficial epithelium, measured by (calibrated) micrometer at 100x magnification.
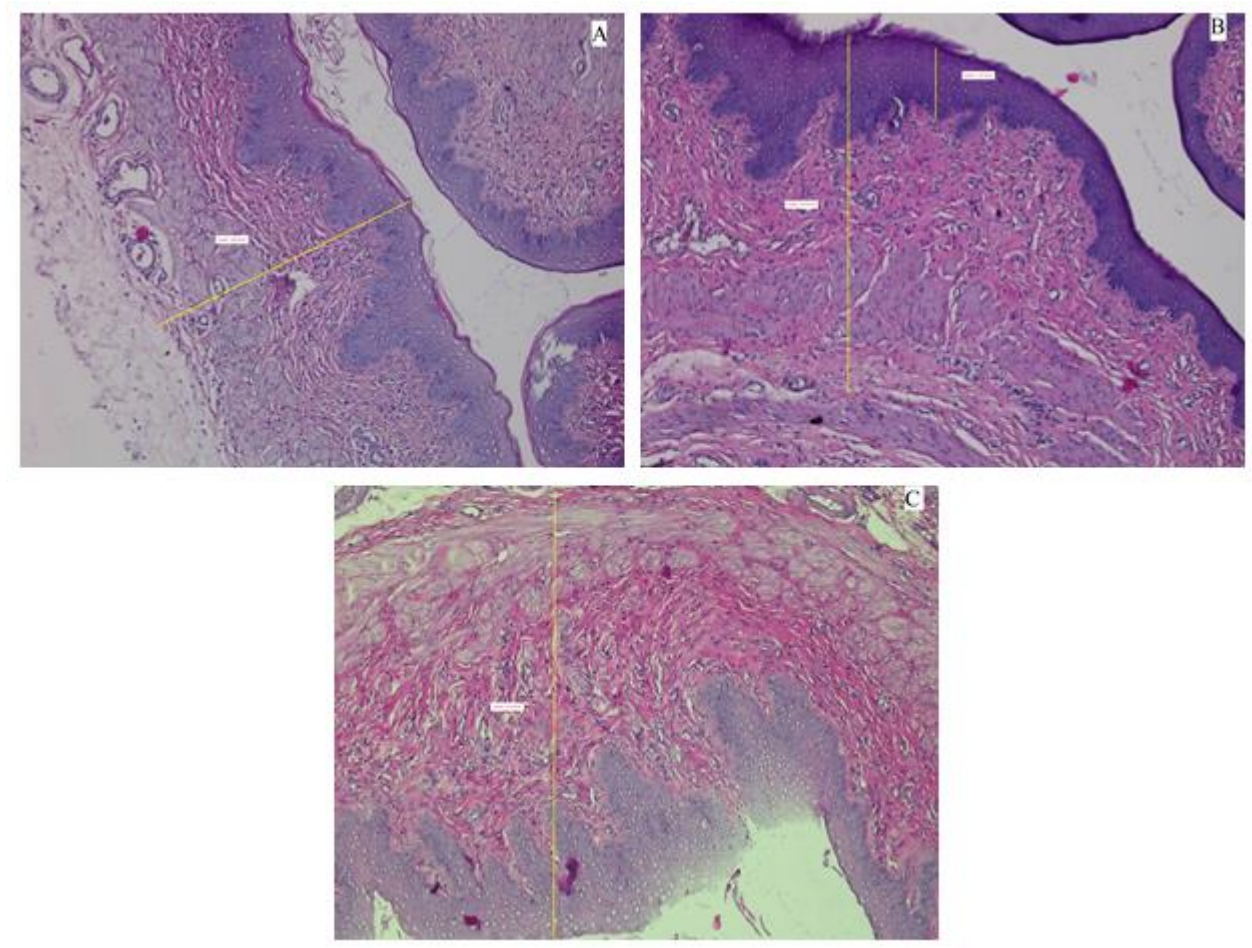

Fig. 1. Wall thickness (yellow line). Slides A, B and C respectively represents treatments K.7, P1.5 and P2.4 (HE staining. 100x magnification; Nikon H600L microscope; camera DS Fi2 300 megapixels).

Table 1. Mean vaginal wall thickness of menopausal mice

\begin{tabular}{lcc}
\hline \multicolumn{1}{c}{ Groups } & Mean of vaginal wall thickness & Standar deviation \\
\hline Distilled water & 643.33 & \pm 58.30 \\
Tomato juice (P1) & 788.33 & \pm 46.45 \\
Red melon juice (P2) & 879.89 & \pm 70.52 \\
\hline
\end{tabular}


Table 2. Minimum, maximum and mean vaginal wall thickness $(\mu \mathrm{m})$

\begin{tabular}{ccccc}
\hline Groups & $\mathrm{n}$ & Minimum value & Maximum value & Mean \pm SD \\
\hline K & 9 & 570.00 & 749.00 & $643.33 \pm 58.30^{\mathrm{a}}$ \\
P1 & 9 & 710.00 & 861.00 & $788.33 \pm 46.45^{\mathrm{b}}$ \\
P2 & 9 & 802.00 & 967.00 & $879.89 \pm 70.52^{\mathrm{c}}$ \\
\hline \multicolumn{7}{l}{ Different letter notations in }
\end{tabular}

Different letter notations in one column show significant differences $(\mathrm{p}<0.05)$

The highest vaginal wall thickness was found in $\mathrm{P} 2$ group which was $879.89 \pm 70.52 \mu \mathrm{m}$, and the lowest in control group $(\mathrm{K})$ of $643.3 \pm 58.33 \mu \mathrm{m}$. The results of Shapiro Wilk normality test revealed $\mathrm{p}=0.378(\mathrm{p}>$ $0.05)$, indicating that vaginal wall thickness the three groups (K, P1 and P2) were normally distributed. Homogeneity test results showed that $\mathrm{p}=0.142(\mathrm{p}>$ $0.05)$, indicating that the thickness of the vaginal wall had homogeneous variant so that it met the requirements for parametric tests (One way Anova). The one-way Anova statistical test results obtained $p=0.00(p<0.05)$, showing that the vaginal wall thickness of the three groups was significantly different. The least significant difference test showed significant differences between all control groups and treatment groups that received tomato juice (P1) and red melon Juice (P2).

\section{DISCUSSION}

This study was an experimental study to identify the effect of tomato juice on the increase of estrogen levels, fibroblasts proliferation and vaginal wall thickness at menopause. In this study we used female Wistar strain rats Rattus norvegicus aged 3-4 months with a body weight of 150 grams \pm 10 grams as many as 24 rats. All experimental animals underwent ovariectomy to obtain menopausal condition. To ensure that all experimental animals had experienced menopause, we performed vaginal swab and obtained a profile of the diestrus phase. Samples were divided randomly into 3 groups, 1 control group and 2 treatment groups which received tomato juice and red melon juice at a dose of 330 $\mathrm{mg} / \mathrm{kgBW} /$ day. We found that the highest mean vaginal wall thickness was in P2 group (879.89 $\pm 70.52 \mu \mathrm{m})$ and the lowest in control group $(\mathrm{K})(643.3 \pm 58.33 \mu \mathrm{m})$.

Menopause is the period of permanent cessation of menstruation due to reduced or lost ovarian activity. At menopause, the ovaries no longer secrete progesterone and 17- $\beta$ estradiol in significant amount. Estrogen deficiency causes atrophy of vaginal wall, so that the vaginal wall will thin out. Estrogen stimulates the maturity of vaginal epithelial cells from the basal stratum to the epithelial layer. In menopause or hypoestrogen state, the vaginal wall will thin out due to atrophy of vaginal epithelial cells (Sawitri 2009). This study also showed that the lowest vaginal wall thickness was found in control group, which was $643.3 \pm 58.33$ $\mu \mathrm{m}$. However, in this study we did not yet know for certain the thickness of the vaginal wall in the rats that had not yet experienced menopause, so it was not identified for certain the extent of vaginal wall thinning due to menopausal conditions.

In group P1 which received tomato juice the mean thickness of the vaginal wall was 788.33 \pm 46.45 . Tomatoes have lignan-type phytoestrogens. This study showed that the inner part of the tomatoes contain compounds that resemble 17- $\beta$ estradiol as much as $1536 \mathrm{pg} / \mathrm{g}$. Phytoestrogen compounds fill the empty estrogen receptor sites and produce estrogenic effects similar to endogenous estrogen. In the case of estrogen deficiency at menopause, phytoestrogen becomes dominant, binds to estrogen receptors that are empty and causes estrogenic effects.

A study has shown that the administration of tomato juice increases estrogen levels in the blood, especially at doses of $330 \mathrm{mg} / \mathrm{kgBW} /$ day (Widjayanti 2013). The ability of phytoestrogen contained in tomato juice binds to estrogen receptor Sex Hormone Binding Globulin (SHBG) plays a role in increasing the hormone estrogen and circulating it in blood vessels. Through its interaction with estrogen receptors, phytoestrogen contained in tomato juice form ligand bonds that act as mediators to stimulate estrogen receptors.

Phytoestrogen will be bound by receptors. The binding between phytoestrogen and its receptors will allow the transmission of intracellular signals that begin with the activation of the phospholipase-C enzyme. This enzyme will convert phosphatidyl inositol diphosphate (PI-2p) into phosphatidyl inositol triphosphate (PI-3p). PI-3p will bind to PI-3p receptors on the endoplasmic reticulum surface and cause calcium gate open, so that intracellular calcium ions increase. These ions will bind to calcineurin in the cytosolic. The calcineurin complex inhibits the activity of the beta-kappa inhibitor $(\operatorname{Ik} \beta)$, so that the nuclear factor kappa beta $(\mathrm{NFk}-\beta)$ undergoes translocation to the cell nucleus and eventually triggers the transcription process that produces proteins that play a role in the process of epithelial proliferation and maturation. The ability of transcription will induce proliferation and maturation of squamosa epithelium and columnar epithelium, resulting in thickening of the epithelial lining on the vaginal surface. 
Increased estrogen levels in the administration of tomato juice affect the proliferation of fibroblasts. Proliferation of fibroblasts is triggered by Transforming Growth Factor beta (TGF- $\beta$ ) (Leask 2004). Previous studies found that in the administration of pegagan extract phytoestrogens, TGF- $\beta$ in the vagina tends to increase (Raden 2010). Phytoestrogen contained in tomatoes given in doses of $330 \mathrm{mg} / \mathrm{kgBW} /$ day is thought to be able to induce an increase in TGF- $\beta$ in the vagina so that the proliferation of fibroblasts occurs in the vaginal walls of the experimental animals (Widjayanti 2013)

Fibroblasts play a role in collagen synthesis and proliferation of vaginal wall epithelial maturation. In addition, the increase in vaginal wall thickness is influenced by increased collagen synthesis and proliferation of vaginal wall epithelial maturation. Estradiol can stimulate the proliferation of vaginal epithelial cells through increased estrogen receptors (Inada 2005). Estradiol is thought to act directly on estrogen receptors in the epithelium or the process of mitogenesis of vaginal epithelial cells (Inada 2005). Increased levels of estrogen in blood due to the administration of tomato juice increases mitogenesis in experimental animal epithelial cells, resulting in an increase in collagen synthesis and trigger proliferation of vaginal wall epithelial maturation. This results in an increase in the thickness of the vaginal wall.

Phytoestrogen is a compound that are similar to $17-\beta$ estradiol so they can bind to estrogen receptors in the vagina and trigger the process of transcription and translation (Bustaman 2008). Proteins produced from the process of transcription and translation include proteins that not only play a role in the process of proliferation, but also in the process of epithelial maturation. Increased transcription ability due to phytoestrogen stimulation, in addition to inducing squamous epithelial cell proliferation and maturation, also induces columnar epithelium, resulting in thickening of the epithelial layer on vaginal surface (Raden 2010). Increased vaginal wall thickness can also be influenced by the effect of high antioxidants in tomatoes which can improve collagenation in vaginal epithelium. This is in accordance with Wahyono's study (2010) that tomato juice can prevent the destruction of collagen in the skin. This may also occur in vaginal epithelium. The antioxidant content in tomatoes can also increase the effect of HSP-70 which can suppress ROS, thereby triggering an increase in the expression of RE $\beta$ and synthesis of type 1 collagen which can cause an increase in wall thickness.

The administration of tomato juice in a dose 330 $\mathrm{mg} / \mathrm{kgBW} /$ day has been proven effective in increasing the thickness of vaginal wall in ovariectomized rats. Tomato juice administered in a dose of 330 $\mathrm{mg} / \mathrm{kgBW} /$ day is thought to trigger collagen synthesis and epithelialization in the vaginal wall which is depleted in menopause due to ovariectomy (Prasetya \& Widjayanti 2015). Increased collagen synthesis, vaginal wall epithelialization and increased glycogen reserves in epithelial lining increase vaginal wall thickness. If the results of this study were applied to humans, the dosage needed to increase the thickness of the vaginal wall would be around 600 grams of fresh tomatoes.

The highest vaginal wall thickness was found in the group that received red melon juice (P2), which was $879.89 \pm 70.52 \mu \mathrm{m}$. Putra's study (2011) showed that red melon was one of the sources of phytoestrogens with estrogen levels measuring $1254.0 \pm 48.1 \mathrm{pg} / \mathrm{ml}$. Melon is a fruit that contains a lot of high sugar and lycopene. Red melon also contains caroteroids which can protect body cells against free radical damage and can also be converted into vitamin A in the body. Melon is known as a fruit that contains high water content. Melon also contains vitamin C (Siswanto 2010). Melon has compounds that are almost the same as the compounds contained in tomatoes, ie. phytoestrogens and licopene, so red melons also have the same effect on the thickness of the vaginal walls of menopausal rats models. Phytoestrogen compounds in red melons trigger an increase in estrogen levels in the blood, thereby increasing the mitogenesis of epithelial cells in the animals, so that collagen synthesis increases and triggers the proliferation of vaginal epithelial maturation. This results in an increase in the thickness of vaginal wall. Increased vaginal wall thickness can also be influenced by antioxidants contained in red melons, which can also improve collagenation in the vaginal epithelium.

One-way Anova statistical test showed $\mathrm{p}=0.00 \mathrm{p}<0.05$, so it can be concluded that the vaginal wall thickness of the three groups was significantly different. The least significant difference test showed significant difference between all control groups and treatment groups that received tomato juice and red melon juice in a dose of $330 \mathrm{mg} / \mathrm{kgBW} / \mathrm{day}$. This study showed that the administration of red melon juice in a dose of 330 $\mathrm{mg} / \mathrm{KgBW} /$ day had the best effect on increasing the thickness of the vaginal wall of menopausal rats models compared with the administration of tomato juice. This was possible because the estrogen content in red melons was higher than the estrogen content in tomatoes. In conclusion, the higher the level of estrogen in blood, the higher the estrogenic effect in the body, which has an impact on increasing the thickness of vaginal wall of menopausal rats models. Red melon can be used as an alternative solution to overcome complaints due to 
decreased estrogen levels during menopause, especially in managing vaginal atrophy.

\section{CONCLUSION}

The highest vaginal wall thickness was found in the treatment group that received red melon juice, which was $879.89 \pm 70.52 \mu \mathrm{m}$ and the lowest was in control group $(\mathrm{K})$, which was $643.3 \pm 58.33 \mu \mathrm{m}$. Anova test showed significant differences between all control groups and treatment groups that received tomato juice and red melon juice in a dose of $330 \mathrm{mg} / \mathrm{kgBW} / \mathrm{day}$. As a conclusion, the administration of $330 \mathrm{mg} / \mathrm{kgBW} /$ day red melon juice has the best effect in increasing vaginal wall thickness of menopausal rats compared with the administration of tomato juice.

\section{REFERENCES}

Arsitya GR, Darsono BS (2010). Karakter fenotip dan kandungan nutrisi melon varietas Baru. A scientic work. Published in Seminar nasional Biologi 24-25 September 2010

Bustamam N (2008). Fitoestrogen dan kesehatan tulang. Bina Widya 19, 146-150

Comitee on Toxicity of Chemicals in Food, Consumers Products and the Environment (2003). Phytoestrogen and health. Available from http://www.food.gov.uk/ multimedia/pdfs/phytoreport0503. Accessed March 2, 2015

Elghany AA (2011). Vaginal atrophy. Available at http://www.hcp.obgyn.net/gynecologic-oncology/content/article>. Accessed April 4, 2015

Fan TF, 2012. Pemberian estrogen topikal pada luka meningkatkan matriks ekstraselular (kolagen, elastin) dan epitelisasi pada kulit tikus wistar (Rattus norvegicus) menopause. Thesis. Denpasar, Universitas Udayana

Ferrero S, Ragni N, Remorgida V (2008). Deep dyspareunia: causes, treatments, and results. Available at http://www.laboratoriosilesia.com/upfiles/sibi/GI08 1073.pdf>. Accessed April 15, 2015

Grady D (2006). Management of menopausal symptom. The New England Journal of Medicine 355, 23382339

Hanna KL, O’Neil S, Wall PM (2010). Intake of isoflavone and lignan phytoestrogens andassociated demographic and lifestyle factors in older Australian women. Asia Pac J Clin Nutr 19, 540-549

Heinrich M, Barnes J, Gibbons S, Williamson EM (2005). Farmakognisi \& fitoterapi. Jakarta, EGC, p 287-288

Ilahy R, Hdider C, Lenucci M, Tlili I, Dalessandro I (2010). Phyitochemical composition andantioxidant activity of high-lycopene tomato (Solanum lycopersicum L.) cultivars grownin southern Italy. Scientia Horticulturae 127, 255-261

Immanuel AI, Wantania J, Suparman E \& Lintong P (2010). Clinical appearance and vaginal cytology of atrophic vaginitis in postmenopausal women. Indones J Obstet Gynecol 34, 91-95

Inada K, Hayashi S, Iguchi T \& Sato T (2005). Establishment of primary culture model of mouse uterine and vaginal stroma for studying in vitro estrogen effects. Available at http://ebm.rsmjournals. com. Accessed January 15, 2013

Kusriningrum RS (2008). Buku perancangan percobaan. Surabaya, Penerbit Dani Abadi, p 17-18

Laswati H (2007). Kombinasi latihan fisik dan pemberian daun semanggi meningkatkan ekspresi Er? dan Erk 1/2 Sel osteoblast mencit menopause. JBP 9, 70-77

Laswati HP, Mahaputra L (2011). Natural phytoestrogen contents in severals fruit and leafs; the future replacement hormone theraphy in menopause women. Jurnal cakrawala 6, 88-95

Liben P (2007). Phytoestrogens as promoters and protectors of breast cancer. Majalah Ilmu Faal Indonesia 6, 1-12

Lukitaningsih E (2010). Fitoestrogen: senyawa alami yang aman sebagai pengganti hormon estrogen pada wanita. Available at http://farmasi.ugm.ac.id/mipto/ file/abstract/79FITOESTROGEN$\% 20 \% 28 \mathrm{Bu} \% 20$ Endang\%20Lukitaningsih\%29.pdf. Accessed February 15, 2015

Mahmudati N (2007). Aksi biologi reseptor estrogen. Majalah Ilmu Faal Indonesia 6, 88-94

Prasetya AW, Widjayanti Y (2015). Effect of tomato (Lycopersicum commune) juice on vaginal wall elasticity in menopausal rats. Folia Medica Indonesiana 51, 132-136

Putra HL (2011). Natural phytoestrogen contents in several fruits; the future replacement hormone therapy in menopause women. Jurnal biosains pascasarjana $13,164-168$

Raden A (2010). Ekstrak pegagan terhadap ekspresi reseptor estrogen, TGF ?, HSP 70, kolagen dan proliferasi epitel pada dinding vagina. A dissertation. Surabaya, Universitas Airlangga

Sawitri IGAA, Fauzi N, Widyani R (2009). Kulit dan menopause manifestasi \& penatalaksanaan. Berkala Ilmu kesehatan Kulit \& Kelamin 21, 48-55

Siswanto (2010). Meningkatkan kadar gula melon. A monograph. Universitas Pembangunan Nasional.

Stansbury JE (2008). Phytoestrogen Review. Available from http://www.botanicalmedicine.org/References/ 09merefs/StansburyPhytoestRef.pdf. Accessed April 15, 2015

Thompson LU, Boucher BA, Cotterchio M, Kreiger N (2006). Phytoestrogen content of foods consumed in 
Canada, including isoflavones, lignans, and coumesta. Nutrition and Cancer 54, 184-201

Wahyono P (2010). Efek jus buah tomat (Lycopersicum pyriforme) terhadap pencegahan fotoaging kulit akibat iradiasi sinar ultraviolet-B. A dissertation. Surabaya, Universitas Airlangga
Widjayanti Y (2013). Pengaruh pemberian jus tomat (Lycopersicum commune) terhadap kadar estradiol, proliferasi fibroblas dan ketebalan dinding vagina tikus model menopause. A thesis. Surabaya, Universitas Airlangga 